\title{
BIOCOMPATIBILITY AND OSTEOGENIC POTENTIAL OF THE NEW BIOCERAMIC ENDODONTIC MATERIAL "ENDOSEAL MTA"
}

\author{
Ali Kamaleldin Rehan*
}

\begin{abstract}
Aim: This study was conducted to analyze the biocompatibility of EndoSeal MTA ${ }^{\circledR}$ in rat subcutaneous tissue and to detect the osteogenic effect of this material.

Methods: The biocompatibility was assessed using the subcutaneous implantation technique. Thirty male albino rats were the subjects used during current research. Animal subjects were anaesthetized, shaved in two areas of the dorsal surface of both of the lower limbs and subcutaneous pockets were made to accommodate the material, which was placed in a polyethylene tubes. Empty polyethylene tubes were used as control. Fifteen animals were sacrificed at each observation period ( 1 month and 3 months implantation). A wide excision of the tissues surrounding the implant was taken, managed and histo-stained with Haematoxylin and Eosin stain for histopathological evaluation of the inflammatory and vascular responses. The Von Kossa histochemical stain was used for demonstration of the mineralized structures. The stained sections were examined using light microscopy. Quantitative analysis of the inflammatory cells was performed using an image analyzer computer system.
\end{abstract}

Results: After one month of tube implantation, mild chronic inflammatory cell infiltration, loosely organized collagen fibers and few slightly dilated blood vessels were observed in the control group. In the experimental group, the inflammatory reaction ranged from mild to moderate. The inflammatory reaction significantly subsided with time in both groups. The difference between the control and experimental group regarding the total number of inflammatory cells was not statistically significant in the both observation periods. No evidence of tissue necrosis was found in the control or experimental groups throughout the experiment.

Conclusions: It could be concluded that EndoSeal MTA $®$ is well tolerated by the subcutaneous connective tissues of rat. The study showed osteogenic potential of EndoSeal MTA®.

* Lecturer of Endodontics, Department of Endodontics, Faculty of Dentistry, Fayoum University, Fayoum 63514, Egypt. 


\section{INTRODUCTION}

A previous definition of biocompatibility might be the capability of a dental material to produce a normal and favorable host tissue reaction in time of its clinical use (Murray et al., 2007). Endodontic therapy aims to proper disinfection and mechanical shaping of the entire root canal systems; then 3D obturation with a biologically compatible, and inert material with dimensional stability (Gomes-Filho et al., 2007).

Strong antimicrobial action, relative biocompatibility, mineralization potential, action to produce effective three-dimensional seal in the presence of wet media, achieving of a chemically based bonding system with dentine, stability in body fluids, post-setting expansion, potent radiopacity, suitable good handling are the points that make bioceramic-based materials an innovative alternatives to conventionally used endodontic materials. (Kossev \& Stefanov 2009; Pradnya el al., 2018).

Number of techniques has been widely done to assess in-vivo tissue responses to different endodontic cements. One of the most applicable and widely used techniques is the surgical placement of the tested agent into the subcutaneous connective tissues of rats (Olsson et al., 1981; Zmener et al., 1988; Economides et al., 1995). The inflammatory effects of endodontic material are assessed by the histopathological microscopic detection of the tissues responses surrounding the implanted agents (Olsson et al, 1981).

Lately, a different calcium silicate-based material, EndoSeal MTA $®$ (Maruchi, Wonju, Korea) was introduced. It is a creamy, premixed, and ready for use injectable whitish hydraulic cement introduced for permanent root canal sealing. EndoSeal MTA ${ }^{\circledR}$ is not soluble, radiopaque, and aluminum-free cement composed mainly of calcium silicate components, that need the existence of moist media to completely set and stabilizes (Zhang et al., 2009).
The manufactures claims that, EndoSeal MTA ${ }$ is composed of mixture of inert and non-irritating salts such as calcium phosphates, calcium di and tri silicates, zirconium oxides, and calcium hydroxide salts. EndoSeal MTA $®$ is similar in its components to white mineral trioxides aggregates (Zhang et al, 2009).

Many literatures showed that Endoseal MTAhave acceptable physic-chemical characteristics (Lim et al., 2015), biocompatibility (Lim et al., 2015), good bond strength performance (Silva et al., 2016), fracture resistance of root dentin (Upadhyay et al., 2017), minimal discoloration (Lee et al., 2016), and superior sealer distribution (Hwang et al., 2015); conversely, there have been no studies regarding the in vivo biocompatibility and osteogenic effect of this material.

Therefore, current research was conducted to analyze the bioactivity (inflammatory response) of EndoSeal MTA $®$ in rat subcutaneous tissues and detect the osteogenic effect (mineralization ability) of this material.

\section{MATERIALS AND METHODS}

Thirty middle-aged male albino rats, weighing 80 to 90 grams for each, all of them were selected to be clinically healthy at the beginning of the experiment were used as subjects in this study. All surgical procedures were done under general anesthesia by intramuscular injection of ketamine solution in the dose of $90 \mathrm{mg}$ per kilogram of body weight associated with xylazine solution $10 \mathrm{mg}$ per kilogram of body weight. Two areas in each rat were shaved, one in each of the lower limbs. These areas were cleaned with $60 \%$ alcohol and dried with gauze. Two transverse incisions were made using bard-parker blade No 15 in a Bard-parker handle No 3. A pouch of nearly $2 \mathrm{~cm}$ size was surgically performed in the subcutaneous tissues by precise dissection using a hemostat to hold the polyethylene tubes. 
The polyethylene tubes $(3 \mathrm{~mm}$ long \& $1.5 \mathrm{~mm}$ internal diameter) were cleaned with $60 \%$ alcohol prior to use. The experimental material was then loaded into the sterile polyethylene tubes, before the surgical procedure. Each rat received 2 tubes, one filled with the material (placed in the subcutaneous tissue of the right limb) and an empty tube used as control (placed in the subcutaneous tissue of the left limb).

After inserting the tubes, the incisions were sutured with black suture. On recovery after the operation the rats were returned to their cages and maintained at regular hygienic care. 15 rats were sacrificed after one month, while the other 15 rats were sacrificed after three months from the implantation time. Animals sacrifice was done by cervical translocation.

Immediately after sacrifice, a wide excision of the tissue surrounding the tubes was taken and the specimens were placed in solution of $10 \%$ solution of neutralized buffering formalin. After fixing of each block specimen for forty eight hours in formalin, the block was bisected along the longitudinal axis of the tube including $2 \mathrm{~mm}$ at both ends. The tube was carefully removed from the specimens so as to reduce damage to the interface area between the experimental material and the tissue.

The tissues were processed for light microscopic study. Each specimen was undergoing dehydration in ascending concentrations of ethyl alcohol, undergone clearing in xylene and vertically placed in paraffin wax. Section of $6 \mu \mathrm{m}$ thickness was taken from specimens placed in paraffin blocks. All sections were deparaffinized, rehydrated and stained with haematoxylin and eosin stain for histopathological examination. Von Kossa histochemical staining was used for detection of mineralized structures related to the implanted material.

The ordinary light microscope was used for histopathological evaluation of the inflammatory responses in the $H \& E$ stained sections using the low and high powers. Moreover, light microscopy was used to examine the histochemically stained sections, as well as for localization Von Kossa reactions within the tissues.

(H\&E) stained sections were assessed by an imaging analyzer computerized program by the software Leica Qwin, which contains a light microscope together with a micro-computerized system able to perform digital imaging analysis. Quantitative analysis of the inflammatory cells was made in 10 separate regions of section at $\mathrm{x} 1000$ magnifications.

These data were represented as mean values \pm SD. Student's t-test was used to compare between the means values. The significance level was set at $\mathrm{p} \leq 0.05$.

\section{RESULTS}

In the control group, one month histological examination revealed mild chronic inflammatory cell infiltration (plasma cells and lymphocytes). Slight dilatation of blood vessels was observed. The implant site was surrounded by loosely organized fibrous capsule. Von Kossa histochemical staining denoted absence of any mineralized tissue.

Regarding experimental group, one month histological examination revealed chronic inflammatory response ranging from mild to moderate. The inflammatory cells were lymphocytes, and macrophages. Few dilated blood vessels were detected. The implant site was surrounded by wavy collagen fiber capsule. Von Kossa histochemical reaction denoted absence of any mineralized tissue or calcification.

After three months, light chronically inflammation cells infiltrates and few small microvasculature were observed in the control group. The implant site was surrounded by a fibrous capsule formed by closely-packed collagen fibers. Von Kossa histochemical staining denoted absence of any mineralized structures. 
A light chronically inflamed response (comprises of lymphocytes and plasma cells) was still observed in the experimental group after three months. The vascular reaction manifested as numerous smallsized blood vessels. The fibrous tissue response consisted of dense fibrosis, showing areas of wavy collagen fiber deposition. The implantation site was surrounded by a densely-packed fibrous capsule. Black Von Kossa histochemical staining could be detected within the tissue reaction surrounding the implantation site in few specimens indicating mineralized structures or calcification.

Using the computed image analyzer; the total number of inflammatory cells was fairly greater in the experimental group compared to the control group in both observation periods. However, this difference was not statistically significant as shown in table (1).

TABLE (1): The recorded means and standard deviation (SD) values of the inflammatory scores for the Control and experimental groups after one month and two months:

\begin{tabular}{|c|c|c|c|c|c|}
\hline \multirow{2}{*}{ Group } & \multicolumn{2}{|c|}{ Control group } & \multicolumn{2}{|c|}{$\begin{array}{c}\text { Experimental } \\
\text { group }\end{array}$} & \multirow{2}{*}{ P- value } \\
\cline { 2 - 5 } & $\begin{array}{c}\text { Mean } \\
(\mathrm{n}=15)\end{array}$ & $\mathrm{SD}$ & $\begin{array}{c}\text { Mean } \\
(\mathrm{n}=15)\end{array}$ & SD & \\
\hline 1 month & 3.15 & 0.75 & 3.55 & 0.90 & 0.33 \\
\hline 3 months & 1.30 & 0.70 & 1.50 & 0.85 & 0.38 \\
\hline
\end{tabular}

SD: Standard Deviation.

P: Probability level.

*: Significant at $P \leq 0.05$.

Regarding the effect of time on inflammatory reaction, the total number of inflammatory cells was higher in the first observation period (one month), compared to the second observation period (three months). The difference was statistically significant in both groups as shown in table (2). The inflammatory reaction declined with time in both control and experimental groups.

TABLE (2): The recorded means and standard deviation (SD) values of the inflammatory scores within the two groups during the two evaluation periods:

\begin{tabular}{|c|c|c|c|c|c|}
\hline \multirow[b]{2}{*}{ Period } & \multicolumn{2}{|c|}{1 month } & \multicolumn{2}{|c|}{3 months } & \multirow[b]{2}{*}{ P-value } \\
\hline & $\begin{array}{l}\text { Mean } \\
(n=15)\end{array}$ & SD & $\begin{array}{l}\text { Mean } \\
(n=15)\end{array}$ & SD & \\
\hline Control group & 3.15 & 0.75 & 1.30 & 0.70 & $0.01 *$ \\
\hline $\begin{array}{l}\text { Experimental } \\
\text { group }\end{array}$ & 3.55 & 0.90 & 1.50 & 0.85 & $0.01 *$ \\
\hline
\end{tabular}

SD: Standard Deviation.

P: Probability level.

$*$ : Significant at $P \leq 0.05$.

\section{DISCUSSION}

The selection of rats as experimental animals in this study was depended on several points in terms of ease of manipulation, mostly short life cycle and popular widely studied anatomy, histology, and genetically related variables (Veloso et al., 2006).

In the present study, tissue reaction was evaluated one month and three months after surgical implantation. The three months observation period revealed the long term tissue reaction of the material.

Empty polyethylene tubes produced no or mild chronically inflammation reactions in majority of the specimens. Histopathological findings of this control group revealed few collagen fibers to wavy collagen fiber deposition in some specimens. There was no evidence of calcification or necrosis. These findings were in accordance with Valera et al (2004), Yaltirik et al (2004) and de Morais et al (2006). This mild reaction may be due surgical trauma during the implantation of tube. 
In the current study, the inflammatory reaction related to subcutaneous implantation of the tested material was mild to moderate in most of the cases and subsided by time. This favorable response could be partially in relation to the existence of calcium hydroxide as one of the EndoSeal MTA ${ }^{\circledR}$ salts. Berbet et al (2002); Huang et al (2002); Miletić et al (2005) suggested that if the material contains calcium hydroxides, which could then enhance reparative process and relief irritating criteria induced by the irritating constitutes of the agent in the surrounding tissue.

In the present study, the level of the inflammatory reactions was reduced at 90 days of tubes implantation, as results stated by Yaltirik et al (2004) and Sumer et al (2006). This response is important for tissue recovery (de Oliveira et al., 2010).

The results of the current study revealed that EndoSeal MTA ${ }^{\circledR}$ does not actually produce any irritating side effects on microvasculature in the connective tissues. These findings are in accordance with some previous biocompatibility tests (Masuda et al, 2005).

In the current study, the deposition of a collagenous fiber encapsulation around the implant material was detected by time; this fibrous response appears to be a normal tissue reaction since such a capsule was also formed in the vicinity of the nearly inert polyethylene tubes in accordance with (Zmener et al., 1988; Ørstavik \& Mjör, 1988).

According to Maher et al (1992), the evidence that the material was encapsulated by fiber collagenous tissues indicates that it was good tolerated with these tissues. Therefore, the fibrous tissue responses observed in relation to the EndoSeal MTA ${ }^{\circledR}$ in the present research emphasizing the biological compatibility of the material.

Therefore, the findings of the current research, in addition to these previously mentioned in literatures, indicate the stimulation of dystrophic mineralization by EndoSeal MTA $®$ in contact with adjacent tissue. As the EndoSeal MTA ${ }^{\circledR}$ contains calcium hydroxide in its formulation; it is possible that this component is responsible for stimulation of mineralization. This is in accordance with Holland et al (1999) who stated that calcium hydroxide in contact with water or tissue fluids, dissociates into calcium plus hydroxyl ions. Ions of calcium may do a chemical reaction with carbon dioxides in the body fluids and form calcium carbonates collections appeared as calcite ions crystalline structures that could direct the formation of mineral tissue deposits.

Furthermore, EndoSeal MTA ${ }^{\circledR}$ contains zirconium oxide $\left(\mathrm{ZrO}_{2}\right)$ which was found to have a bone inducing potential, according to Sollazzo et al (2008), who studied the genetic proteins which were differently regulated in osteoblastic cells directed to zirconium oxide coating, with the aid of microarray techniques. The relatively expressed genetic media covered a wide range of functions and actions: cells cyclic regimen, signals communication, immunology, and cytoskeletal compounds. The effect of coating dental implants with zirconium oxide on improving osseointegration was reported in rabbit tibia (Sollazzo et al 2008). Therefore, it can be concluded that zirconium oxide together with calcium hydroxide may have a role in stimulating mineralization as detected in the current research.

EndoSeal MTA $®$ could contain several forms and extra levels of the oxide compounds known to have antibacterial activities such as $\mathrm{Na} 2 \mathrm{O}, \mathrm{MgO}$, $\mathrm{Al} 2 \mathrm{O} 3, \mathrm{SO} 2$, and $\mathrm{Fe} 2 \mathrm{O}$ than Endo-Sequence BC. (Shin et al., 2018).

Using premixed cements prevents the relative of heterogeneous mix during on-site mixing. Literatures including other bioceramic endodontic materials already showed mineral tissues depositions (Güven et al., 2013) and perfect tissues responses to pulpotomy therapies (Azimi et al., 2014).

Many literatures on bioceramic based materials have showed less inflammation mediators and 
good osteoblastic expressions, indicating the good biocompatibility of bioceramics (Chang et al., 2014; Bósio et al., 2014). These previous results on the tissue response of bioceramic sealers matched the results of present research.

Calcium silicate based materials when becomes in contacting with the natural existing moist contents inside lumen of dentine tubules, calcium silicate ions react chemically with the water $(\mathrm{H} 2 \mathrm{O})$ producing calcium-silicate hydrogel plus calcium hydroxides; calcium hydroxides react with calcium phosphates ions forming hydroxyapatites and water. $\mathrm{H} 2 \mathrm{O}$ is suspected to start this reaction ring many times (Zhang et al., 2010). The great scores of calcium and silicones could justify the excellent biocompatibility of EndoSeal MTA®.

Zhang et al (2013) concluded that bioceramic agents showed in significant way regulated activation of alkaline phosphatase enzyme (ALP) and expressions of dentin sialophosphoproteins (DSPP), dentin matrix protein 1 (DMP 1), and osteocalcins (OCN) of human dental pulp stem cells; these genes were combined with mineralizations and odontoblastic histodifferentiation.

A great feature of these bioceramic agents is its capability to produce hydroxyapatites and optimally induce chemical attachment between dentine and the bioceramic agent (Wang, 2015). An alkaline $\mathrm{pH}$ could refer to osteogenic potential, biocompatibility, and antimicrobial property of ceramic based biomaterials (Lee, 2017).

\section{CONCLUSION}

With regard to limits of current research, it could be stated that EndoSeal MTA ${ }^{\circledR}$ was good tolerated by the subcutaneous tissues of rat. The study showed osteogenic potential of EndoSeal MTA $®$, which can accelerate healing of periapical tissues after root canal therapy.

\section{REFERENCES}

1. Azimi S, Fazlyab M, Sadri D, Saghiri MA, Khosravanifard B, Asgary S. Comparison of pulp response to mineral trioxide aggregate and a bioceramic paste in partial pulpotomy of sound human premolars: a randomized controlled trial. Int Endod J. 2014; 47(9):873-81.

2. Berbert FL, Leonardo MR, Silva LA, Tanomaru Filho $\mathrm{M}$, Bramante CM: Influence of root canal dressings and sealers on repair of apical periodontitis after endodontic treatment. Oral Surg Oral Med Oral Pathol Oral Radiol Endod. 2002; 93(2):184-9.

3. Bósio CC, Felippe GS, Bortoluzzi EA, Felippe MCS, Felippe WT, Rivero ERC. Subcutaneous connective tissue reactions to iRoot $\mathrm{SP}$, mineral trioxide aggregate (MTA) Fillapex, DiaRoot BioAggregate and MTA. Int Endod J. 2014;47(7):667-74.

4. Chang SW, Lee SY, Kang SK, Kum KY, Kim EC. In vitro biocompatibility, inflammatory response, and osteogenic potential of 4 root canal sealers: Sealapex, Sankin apatite root sealer, MTA Fillapex, and iRoot sp root canal sealer. J Endod. 2014;40(10):1642-8.

5. De Oliveira RL, Oliveira Filho RS, Gomes Hde C, de Franco MF, Enokihara MM, Duarte MA: Influence of calcium hydroxide addition to AH Plus sealer on its biocompatibility. Oral Surg Oral Med Oral Pathol Oral Radiol Endod. 2010; 109(1):e50-4.

6. De Morais CA, Bernardineli N, Garcia RB, Duarte MA, Guerisoli DM: Evaluation of tissue response to MTA and Portland cement with iodoform. Oral Surg Oral Med Oral Pathol Oral Radiol Endod. 2006; 102(3):417-21.

7. Economides N, Kotsaki-Kovatsi VP, Poulopoulos A, Kolokuris I, Rozos G, Shore R: Experimental study of the biocompatibility of four root canal sealers and their influence on the zinc and calcium content of several tissues. J Endod. 1995; 21(3):122-7.

8. Gomes-Filho JE, Gomes BP, Zaia AA, Ferraz CR, SouzaFilho FJ: Evaluation of the biocompatibility of root canal sealers using subcutaneous implants. J Appl Oral Sci. 2007; 15(3):186-94.

9. Güven EP, Taşlı PN, Yalvac ME, Sofiev N, Kayahan MB, Sahin F. In vitro comparison of induction capacity and biomineralization ability of mineral trioxide aggregate and a bioceramic root canal sealer. Int Endod J. 2013;46(12):1173-82.

10. Holland R, Souza V, Nery MJ, Otoboni Filho JA, Bernabé PFE, Dezan. Reaction of dog's teeth to root canal filling with mineral trioxide aggregate or a glass ionomer sealer. J Endod 1999; 25:728-30. 
11. Huang FM, Tai KW, Chou MY, Chang YC. Cytotoxicity of resin-, zinc oxide-eugenol-, and calcium hydroxide-based root canal sealers on human periodontal ligament cells and permanent V79 cells. Int Endod J. 2002; 35(2):153-8.

12. Hwang JH, Chung J, Na HS, et al. Comparison of bacterial leakage resistance of various root canal filling materials and methods: confocal laser-scanning microscope-study. Scanning 2015; 37:422-8.

13. Kossev D \& Stefanov V. Ceramics-based sealers as new alternative to currently used endodontic sealers. Roots 2009; 1: $42-48$

14. Lim ES, Park YB, Kwon YS, et al. Physical properties and biocompatibility of an injectable calcium-silicate-based root canal sealer: in vitro and in vivo study. BMC Oral Health 2015; 15:129.

15. Lee DS, Lim MJ, Choi Y, et al. Tooth discoloration induced by a novel mineral trioxide aggregate-based root canal sealer. Eur J Dent 2016; 10:403-7.

16. Lee JK, Kwak SW, Ha JH, Lee WC, Kim HC. Physicochemical Properties of Epoxy Resin-Based and Bioceramic-Based Root Canal Sealers. Bioinorganic Chemistry and Applications, Volume 2017, Article ID 2582849, doi:10.1155/2017/2582849. 2017.

17. Maher WP, Johnson RL, Hess J, Steiman HR: Biocompatibility of retrograde filling materials in the ferret canine. Amalgam and IRM. Oral Surg Oral Med Oral Pathol. 1992; 73(6):738-45.

18. Masuda YM, Wang X, Hossain M, Unno A, Jayawardena JA, Saito K, Nakamura Y, Matsumoto K: Evaluation of biocompatibility of mineral trioxide aggregate with an improved rabbit ear chamber. J Oral Rehabil. 2005; 32(2):145-50.

19. Miletić I, Devcić N, Anić I, Borcić J, Karlović Z, Osmak M: The cytotoxicity of RoekoSeal and AH plus compared during different setting periods. J Endod 2005; 31(4):307-9.

20. Murray PE, García Godoy C, García Godoy F: How is biocompatibility of dental biomaterials evaluated? Med Oral Patol Oral Cir Bucal. 2007; 12 (3): E258-66.

21. Olsson B, Sliwkowski A, Langeland K: Subcutaneous implantation for biological evaluation of endodontic materials. J Endod. 1981; 7(8):355-69.

22. Pradnya V. Bansode, Seema D. Pathak, M.B. Wavdhane, Padmabhushan V. Chavan A Review of Bioceramic Sealers in Endodontic. Journal of Dental and Medical Sciences. Volume 17, Issue 5 Ver. 12(May. 2018), PP 82-86

23. Ørstavik D, Mjör IA: Histopathology and x-ray microanalysis of the subcutaneous tissue response to endodontic sealers. J Endodon 1988; 14: 33-44.
24. Sollazzo V, Palmieri A, Pezzetti F, Bignozzi CA, Argazzi R, Leo Massari L, Brunelli G, Carinci F: Genetic effect of zirconium oxide coating on osteoblast-like cells. J Biomed Mater Res: Appl Biomater. 2008; 84B: 550 - 558.

25. Sumer M, Muglali M, Bodrumlu E, Guvenc T: Reactions of connective tissue to amalgam, intermediate restorative material, mineral trioxide aggregate, and mineral trioxide aggregate mixed with chlorhexidine. J Endod. 2006; 32(11):1094-6.

26. Silva EJ, Carvalho NK, Prado MC, et al. Push-out bond strength of injectable pozzolan-based root canal sealer. J Endod 2016; 42:1656-9.

27. Upadhyay ST, Purayil TP, Ginjupalli K. Comparative evaluation of fracture resistance of endodontically treated teeth obturated with pozzolan-based MTA sealer and epoxy resin-based sealer: an in vitro study. World J Dent 2017; 8:37-40.

28. Valera MC, Leonardo MR, Consolaro A, Matura FS: Biological compatibility of some types of endodontic calcium hydroxide and glass ionomer cements. J Appl Oral Sci. 2004; 12(4): 294-300.

29. Veloso HH, do Santos RA, de Araújo TP, Leonardi DP, Baratto Filho. Histological analysis of the biocompatibility of three different calcium hydroxide-based root canal sealers. J Appl Oral Sci. 2006; 14(5):376-81.

30. Wang, Z. (2015). Bioceramic materials in endodontics. Endodontic Topics, 32(1),30.

31. Wang, Z. (2015). Bioceramic materials in endodontics. Endodontic Topics, 32(1),30.

32. Yang Q, Troczynski T, Liu DM. Influence of apatite seeds on the synthesis of calcium phosphate cement. Biomaterials 2002; 23:2751-60.

33. Yaltirik M, Ozbas H, Bilgic B, Issever H: Reactions of connective tissue to mineral trioxide aggregate and amalgam. J Endod. 2004; 30(2):95-9.

34. Zhang W, Li Z, Peng B: Assessment of a new root canal sealer's apical sealing ability. Oral Surg Oral Med Oral Pathol Oral Radiol Endod. 2009; 107(6):e79-82.

35. Zhang W, Li Z, Peng B. Effects of iRoot SP on mineralization-related genes expression in MG63 cells. J Endod 2010; 36:1978-82.

36. Zhang S, Yang X, Fan M. BioAggregate and iRoot BP Plus optimize the proliferation and mineralization ability of human dental pulp cells. Int Endod J 2013; 46:923-9.

37. Zmener O, Guglielmotti MB, Cabrini RL: Biocompatibility of two calcium hydroxide-based endodontic sealers: a quantitative study in the subcutaneous connective tissue of the rat. J Endodon 1988; 14(5): 299-305. 